\title{
Conversion Strategies and the Power to Define: British and American Muslim Performance in Bourdieu's Field of Art
}

\author{
Yolanda van Tilborgh \\ Faculty of Philosophy, Theology and Religious Studies, Radboud University Nijmegen, The Netherlands \\ Faculty of Social and Behavioral Sciences, University of Amsterdam, The Netherlands
}

Copyright $\mathrm{O} 2016$ by authors, all rights reserved. Authors agree that this article remains permanently open access under the terms of the Creative Commons Attribution License 4.0 International License

\begin{abstract}
When a number of Muslims in non-Muslim majority countries in North America and Western Europe gained attention as upcoming performers in the genres of hip-hop, stand-up comedy and performing poetry in the last decades, this was perceived as a remarkable phenomenon by public media and social scientists. Firstly, a lot of these performers bring Islam to the fore in their artistic expressions in the public domain, whereas, secondly, the relation between art and Islam is perceived as troublesome at various social levels. While gaining visibility after the multiple terrorist attacks, the phenomenon of entertaining Muslims is often understood as an expression of post-Islamism, the attitude of tolerance in Islamism that synthesizes contrasting opinions. Expressions of Muslims are explained as "purposeful art" and the performing arts as a repertoire to diffuse (positive) Islamic values. To comprehend the complex manifestations of religion in modern day societies as reflected by these trends, existing social perspectives are now no longer considered satisfactory. The forthcoming paper examines if the perspectives of symbolic interactionist, process and relational sociology are indeed insufficient to discuss and explain several significant understandings of Muslims, their practices and discourse regarding (popular) art. Do all of these artists equally pursue art with a social purpose? Are Islamic authoritative voices significant to everyone? Or do the artists follow wayward conversion strategies in order to achieve their objectives and become established?
\end{abstract}

Keywords Muslim Performing Artists, Field of Art, Ethnicity in Islam, Islamic Conversion, Immigrants, Cultural Distinction, Defining Power, Conversion Strategies

\section{Introduction}

After the 9/11 attacks on the Twin Towers in New York but still before the Islamic State (IS, ISIS or Daesh) onslaught in Europe, a number of Muslims in the United Kingdom (UK) and the United States (USA) gained attention as performers in the genres of hip-hop, stand-up comedy, spoken word and theatre. On stage, many of these performers took Islam as an important point of departure; they might even put Islam to the fore and center of their artistic expressions (Mandaville 2009)[1]. According to the literature on Muslims in the performing arts in the Middle East, Europe and the USA, through Islamic references in content, appearance and justification Muslims expose their Islamic ethos more visibly in popular culture by using art to support their religious, cultural and, to a lesser degree, political goals (Mandaville 2009[1]; Abdul-Khabeer 2007[2]; Boubekeur 2007[3]; Herding 2013[4]; Kubala 2005[5]; Mohaiemen 2008[6]; Solomon 2006[7]; Swedenburg 2001[8]; Tartoussieh 2007[9]; Van Nieuwkerk 2008[10]; Winegar 2008[11]).

At the time, these Muslim performing artists were perceived as a remarkable new phenomenon in popular culture by public media and social scientists. In their work, the artists mix contemporary styles with their Islamic ways. Meanwhile, they have to cope with divergent interpretations concerning the issue of how to relate art to religion. Similar to discussions in Christianity about whether art can serve as praise of God and motivate ethical action, or, on the contrary, stirs immodest behavior (Brown 2000)[12 p55], there is an ongoing discourse among many Muslims and Islamic authoritative voices on the (im)permissibility of (popular) art in Islam - what is Islamically allowed, halal, disapproved of, haram, or undecided, mubah - even in Western democracies (Mandaville 2009[1]; Abdul-Khabeer 2007[2]; Aidi 2014[13 p44-70]; Bayat 2007[14]; Otterbeck 2008[15]; Shiloah 1995[16]). These discussions, shaped by transnational and global religious and secular trends, problematize expressions with women on stage, humor and especially the use of musical instruments.

This phenomenon takes place among the growing Muslim minorities in the West. Muslims make up for almost five 
percent in the $\mathrm{UK}^{1}$ and near to one percent in the USA in 2010, which will presumably be doubled in $2050 .^{2}$ British and North American Muslims represent an immense range of ethnic groups, including African American, Trinidadian, Egyptian and Pakistani Muslims. The migration of Muslims to Western Europe began in the 1950s and 60s, largely due to European economic prosperity and the consequent recruitment of low-skilled laborers from various continents, whereas the USA, especially after its Immigration Act of 1965, has attracted many Muslim students and professionals from South Asia and the Middle East (Lapidus 2002)[17 p790-805]. In the United States, besides those with immigrant background, an important part of the Muslim community consists of African American and White convert Muslims, who are born there. ${ }^{3}$ Indigenous Muslims and first and second-generation Muslim immigrants are all differently concerned about cultural questions of assimilation, integration and ways of citizenship as well as about adhering to an ethnic or universalist kind of Muslim identity (Khan 2003[18]; Lapidus 222[17 p803-05]).

Contemplating the significance of the phenomenon of Muslim performing artists, the question emerges if British and North American performing artists predominantly act from essential religious and cultural views or are the regular mechanisms of producing art as to non-Muslim artists crucial as well?

\section{Theoretical Framework}

Alongside the extensive human migration from various Muslim-majority countries to Muslim-minority countries in the West, in particular the global trend of Islamic Revival is taken as a factor to the growing activity of Muslims in (alternative) music, comedy and drama. Notably since the 1990s, the trend toward greater piety started in the Middle East side by side with the modernization of societies comprising state constitution and capitalism. Seeking to reform the religious and social life of the Muslim community, this revival engendered a growing adoption of what is considered to be "Islamic culture" and "Muslim values," manifested by participation in the annual pilgrimage to Mecca, hajj, and a more stringent separation of the sexes (Esposito 1998[19 p34-61]; Kepel 2006[20 p69-75]; Lapidus 2002[17 p817-28]; Roy 2004[21 p233]). Many religious artistic expressions are thus understood from the need to (re)formulate what is Islamic and Muslim in discussing the authentic values of Muslims and their communities regarding the West and the Middle East (Mandaville 2009[1]; Boubekeur 2007[3]; Kubala 2005[5];

1 Available at: www.pewresearch.org/fact-tank/2015/11/17/5-facts-aboutthe-muslim-population-in-europe/ (accessed January 18, 2016).

2Available at:www.pewresearch.org/fact-tank/2015/04/14/muslims

-expected-to-surpass-jews-as-second-largest-u-s-religious-group/

(accessed January 18, 2016).

3 Available at: www.pewresearch.org/fact-tank/2015/07/27/the-most-and -least-racially-diverse-u-s-religious-groups/ (accessed January 18, 2016).
Otterbeck 2008[15]; Winegar 2008[11]; Roy 2004[21]). ${ }^{4}$

According to the literature, motivated by the rise of the new religious ethos alternative forms of restricted art have emerged. Central to "halal songs," "halal television soaps," "clean cinema" and "Islamic theater" are the control of bodily performance alongside controlling artistic intentions (Kubala 2005[5]; Tartoussieh 2007[9]; Van Nieuwkerk 2008[10]). Through moral confirmation deriving from the need for social progress, "purposeful art" or "art with a mission" (al-fann al-hadif) has become a source of Islamic legitimation of art and entertainment. Some devout artists, such as Sami Yusuf, develop the traditional, restricted musical forms by turning anasheed - Islamic songs with just the hand drum - into spiritual entertaining songs, expressed in the blending of English and Arabic styles and supported by (stringed) musical instruments (Kubala 2005)[5].

In the Middle East, ideas on art and culture have derived from scholars and their philosophies on how to cope with modernization, secularization and globalization. When Egypt opened itself to the forces of the world market, the erosion of simple traditions accelerated, which symbolized a deepening of Westernization (Baker 2003) [22 p68]. In that social climate, the Egyptian state had failed to articulate a coherent cultural identity or national project (Winegar 2008)[11]. Filling this gap, intellectuals of the "New Islamist Trend," an outgrowth of the centrist Islamic mainstream (Wassatteyya), developed perspectives to the kind of modernity that accommodates Islam. Aligning the interpretation of the Quran with progress and social cohesion by thought and practice, they started to cultivate a positive perception of Islam instead of an Islam based on fear (Baker 2003)[22]. The pragmatic "New Islamists," represented by Islamic scholars Yusuf al-Qaradawi and late Mohammed al-Ghazali al-Saqqa, criticize the hard-line views of Islamists who approve of violent extremist actions against many forms of art by attacks on theaters or musical concerts. The sheikhs counter the negative attitude toward art by relying on several sayings in the Quran and Hadith that give credit to art (Winegar 2008[11]; Baker 2003[22]). Al-Ghazali has argued for a renewal of the roots of community in Islam, which had been able to establish a powerful civilization fourteen centuries ago. According to these scholars, a reformation of the state and society through integrating Islamic values should also allocate a role to the arts. Although, in their views, Islam does not condemn artistic expression in literature, dance, music nor in song, some lyrics set to music and ways of performance could however be inappropriate to convey Islamic meaning (Baker 2003[22 57-63]; Otterbeck 2008[15]).

The concept of connecting the arts to ideals concerning "Islamic community" and "Islamic identity" is also conveyed by several Islamic televangelists, in particular Amr

4 With religious artistic, I mean the blending of religious and artistic cultural tastes and orientations. 
Khaled and Moez Masoud. In their views, conscious artistic expressions especially could counter the threat of moral decline and the loss of authenticity due to globalization and secularization in the Middle East and, particularly, Egypt (Kubala 2005[5]; Winegar 2008[11]). To cope with post-colonialism and the import of pop cultural trends, Muslims should participate in social projects to reform the ummah and society at large with art and music that are useful and moral.

The intellectual opponents in the debate on how to reform society, for instance the assassinated Egyptian human rights activist Farag Foda, have emphasized the secularist principle that a "religious state" cannot provide the kind of governance required by the conditions of the present century (Baker 2003)[22 p6]. Similarly distinguishing itself from the moderate and (ultra) conservative views on the arts, the liberal outlook of Lebanese Islamic scholar Ibrahim Ramadan al-Mardini acknowledges fields in which Islamic jurisprudents should not intervene, particularly the field of art (Otterbeck 2008)[15].

Nevertheless, the philosophies of the New Islamists, including Al-Ghazali and especially Al-Qaradawi, have extended into transnational arenas (Baker 2003)[22 p77]. In the debate on the Islamic law for Muslim minorities, these moderate views are important for legal decision-making in Western contexts. Al-Qaradawi's interpretations in the European Council for Fatwa and Research (ECFR) support the principle of making social realities manageable for Muslims instead of proposing more interdictions (Al-Qaradawi 2001)[23]; Gräf 2013[24]).

Globalized communications and media technologies have further reinforced the spread of cultural and religious expressions of Islamic teachers and new Muslim artists. As discussed above, the popular sheikhs and television preachers from Egypt and Qatar, such as Al-Qaradawi, Khaled and Masoud, manifest themselves as an encouraging force to the kind of art that aims for social, religious and personal reform by focusing on its message (Kubala 2005 [5]; Tartoussieh 2007[9]; Winegar 2008[11]; Otterbeck 2008[15]). Similarly in the UK, (invited) Islamic preachers, such as Suhaib Webb, Khalid Yasin and Abdur-Raheem Green, influence the debate on art and Islam in order to control the preferred socio-religious objectives of art (Mandaville 2009)[1].

The literature suggests that a growing middle class of Muslims has prompted the phenomenon of religiously inspired (popular) art. In Egypt, these expressions are explained to satisfy the need for appropriate entertainment among socially risen Muslims with growing "pious sensibilities" (Tartoussieh 2007[9]; Van Nieuwkerk 2008[10]), while in France religious artistic expressions are considered to be the new tools of an engaged post-Islamist elite (Boubekeur 2007)[3].

In Europe, many Muslims with immigration histories share experiences of social exclusion and stigmatization. In the 1980s, especially in France, the militant Islamic revival movement Islamism sought to battle discrimination against
Muslim migrants. The movement mobilized Muslims with lectures, not with art (Boubekeur 2007)[3]. In the twenty-first century, however, post-Islamism emerged as a cultural project of Islamism, displaying a more tolerant attitude by seeking cultural inclusiveness through synthesizing divergent religious opinions (Bayat 2007; 2013)[25,26]. The project of post-Islamism is considered to have brought about the new Muslim expressions in art in different national contexts (Boubekeur 2007[3]; Tartoussieh 2007[9]; Van Nieuwkerk 2008[10]; LeVine 2008[27]). Reflecting post-Islamism in France, politically engaged Muslims, ${ }^{5}$ who were disappointed with the results of (militant) Islamism, began to use the soft cultural means of popular arts such as comedy, theater and television as a repertoire to disseminate their adapted Islamic values (Boubekeur 2007)[3]. Particularly to tackle stigmatization after 9/11, which made clear that Muslims have to deal with degrading depictions proceeding from the civilizationversus-barbarity dichotomy (Mamdani, 2005[28]; Morey \& Yaqin, 2011[29]), Muslim artists started to explore the means of comedy and music instead of militancy. For them, according to Amel Boubekeur, art has to do with ethical attitudes, anti-stigmatization and successfulness. Reflecting a new "Islamic identity," this confident kind of Islam, which transcends the problematic immigrant Muslim image, is called "Cool Islam." 6

On the European continent, several Muslim hip-hop bands have used the anti-racist style of African American hip-hop subculture, hereby creating an underground arena for anti-Islamophobic mobilization (Solomon 2006[7]; Swedenburg 2001[8]). Compared to the literature on the Middle East, contemporary artists in Europe and the USA are concerned with their common Muslim identity as a conflation of strands in Islam and specific ethnic backgrounds (see also Mohaiemen 2008)[6]. According to Alim, Islamic beliefs guide rappers toward "nation building activities" for socio-economically deprived African American citizens by way of revitalizing local communities and giving talks on civic engagement in prisons (2005)[30]. Moreover, when American Muslim artists draw their personal and collective identities from the style of "Islamic hip-hop," Suad Abdul-Khabeer argues, this may be considered part of the larger project to develop an "American Muslim culture" (2007)[2]. This typical culture may reflect the emergence of the American Muslim identity, which Muqtedar Khan explains in relation to a liberal understanding of Islam in tune with dominant American values such as religious tolerance, democracy and pluralism (Khan 2003)[18].

Whereas Abdul-Khabeer predominantly describes indigenous Muslim artists in the USA, Thijl Sunier is critical

5 To Boubekeur, these Muslims are people who "make recourse to a social discourse of self-definition marked by a public Islamic religiosity" (Boubekeur 2007)[3].

6 Available: news.bbc.co.uk/2/hi/europe/7266729.stm (accessed February $6,2012)$. 
about the academic use of "Muslim culture," particularly in Europe, as a separate explanatory category instead of a "category of practice" (Sunier 2012[31]; Brubaker \& Cooper 2000 [32]). He argues that since the 1980s, "culture" which includes religion - has developed into a fundamental concept with which the backgrounds of migrants are understood at the cost of other explanatory factors in Western Europe. In the ensuing decades, according to Sunier's view on culturalism, the aim of many social scientists has become to demonstrate the fundamental cultural differences between Muslims and the rest of society, in the sense of "otherness."

In addition, José Casanova observed that the majority of the European population equalizes the religious decline in Europe with "progressivity" and "modernity," whereas Islam has become regarded as "the other" of Western secular modernity (Casanova 1994, 2004)[33,34]. In 2011, he concluded that, in order to comprehend the complex manifestations of religion in modern day societies, we are in need of new social scientific models because the existing perspectives seem to be outdated as far as religion is concerned. $^{7}$

To learn more about the concerted or divergent efforts of Muslim performing artists in Britain and the United States, the sociological theory of symbolic interactionism, process and relational theories offer perspectives that are not exclusively related to the cultural religious identities of artists. Howard Becker developed the concept that represents art principally as a collective product (Becker 1982)[35]. An art world is an art-related social network with shared understandings and ways of doing things, i.e., conventions, which emerge from social interaction between artists, managers, producers and certain audiences.

While the art world is very much characterized by consensus between its participants, the concept of Pierre Bourdieu of the field of art concerns a social arena, in which participants struggle and compete for a better position (Bourdieu 1996, 2009)[36,37]. In the social hierarchy of the field, the position of an artist improves by gaining symbolic capital, i.e., artistic prestige and authority. The hierarchy determines whose definition of "high art" and "popular art" art becomes dominant. Bourdieu calls the mechanisms of competition in the field the rules of art. These rules can be understood as general tools to explain the field, which can therefore be interestingly used to better understand Muslim performing artists in their transnational Anglophone contexts.

7 Van der Zwaag, K. (2011) "Casanova: We kunnen niet meer gedachtenloos seculier zijn." Reformatorisch Dagblad. Available at: www.refdag.nl/kerkplein/kerknieuws/casanova we kunnen niet meer gedachteloos seculier zijn 1539211 (accessed November $2 \overline{8}, 2015$ ). Based on the lecture God in a Cold Climate. Religion in the Secular Public Sphere: Challenges and Responses by José Casanova at Radboud University Nijmegen, the Netherlands, March 10, 2011.

\section{Research Question}

The literature related to the topic of Muslims, art and Islam mention to a certain degree the role of the state, religious institutions, ethnicity and socio-economic circumstances, which present a very notable though partial explanation of the phenomenon of Muslim performing artists in popular culture in the Middle East, Europe and the USA. At the same time, the expressions Islamic capital, Islamic heritage, Islamic identity, Islamic lifestyle, Muslim culture, Muslim sensibilities, Cool Islam, Islamic purposefulness, heavy metal Muslims, Muslim rap and Islamic hip-hop (Abdul-Khabeer 2007[2]; Boubekeur 2007[3]; Herding 2013[4]; Kubala 2005[5]; LeVine 2007[27]; Van Nieuwkerk $2008,2013[10,38]$; Winegar 2008[11]) make the phenomenon very much specific to the group of pious Muslims. For example: Is art with a social purpose a characteristic of Muslim performing artists? Are all Muslim artists equally inspired by the Islamic Revival? The terms raise questions regarding to what extent contemporary Muslims in the performing arts are part of the development of a "Muslim culture" and a related cultural, i.e., faith- and/or ethnic-oriented, identity. Whether Muslim performing artists can be regarded part of the field of art and its cultural mechanisms remain undefined. So, from the perspectives of religion, ethnicity and general cultural mechanisms, my question is: How is the field of Muslim performing artists actually structured and differentiated in Britain and the United States - or is it a homogeneous entity?

\section{Research Methodology}

The present paper is based on a broad ethnographic study of Muslim performing artists in the UK and the USA ${ }^{8}$ for which the empirical findings were collected between 2009 and 2012. The findings are studied from the concept of intersectionality through focusing, among others, on the significance of gender, class, ethnic and religious background. At the time of research on how Muslim artists synthesize their artistic identity with their religious conceptions, the artists were engaged in cultural production in Anglophone hip-hop \& alternative music, spoken word \& poetry, storytelling, theater \& acting, stand-up comedy, film performance and contemporary art on stage. ${ }^{9}$ They are mainly self-acclaimed Muslims who have brought Islam or experiences related to being Muslim to the fore in at least one of their artistic performances. Besides drawing on secondary literature from academic sources as well as traditional and digital media, semi-structured in-depth interviews on art,

8 This study Singing or Sinning: Cultural Orientations among British and American Muslim Performing Artists is partly funded by the Netherlands Organization for Scientific Research NWO and has respectively taken place at Radboud University Nijmegen (Religious Studies) and University of Amsterdam (Sociology).

9 The broader study has left out artists of productions in other (Urdu, Punjabi) languages. 
culture and Islam were conducted with sixty-five Muslim performing artists and eight stakeholders, including art managers and Islamic teachers in the UK and the USA. ${ }^{10}$ In addition, twenty-three similar participants in art (artists and stakeholders) were studied through short interviews and/or secondary sources. ${ }^{11}$ The eventual focus group of seventy artists includes religiously strictly practicing, moderately practicing and less strictly practicing Muslims; for reasons of comparison, there is a small category of artists with Muslim background. ${ }^{12}$ Moreover, I attended seventy religious artistic events, including biographical artistic performances, to collect additional ethnographic data on the orientations of Muslim performing artists. This was done through participant observations. ${ }^{13}$ Altogether, to expose general cultural mechanisms among Muslim artists, I will analyze different practices of these performers with Anglophone productions based on information from interviews, secondary sources and cultural events related to ninety-six artists and art advisers in the UK and the USA.

\section{Empirical Findings}

After 9/11, British and North American Muslim performing artists have started to criticize the deviant representations of Muslims by society as well as by the culture industry in Hollywood (see also Horkheimer \& Adorno 2002[39]; Shaheen 2001[40]). As a counter reaction to stigmatization and the regular consideration of mainstream popular art and gangsta hip-hop in particular as meaningless, sexualized or criminalized, many of them have started to strive for a kind of conscious art that is truthful and leads to awareness about justice and injustice (see also Rose 1994, 2008)[41,42]. Similar to artists in any art world (Becker 1982) [35], they have developed several shared views among each other. For instance, many British and American Muslim artists are eager to "voice the voiceless." These voiceless people may be, for example, uneducated Muslims but also non-Muslims who are excluded by the overall society because of being poor or regarded as deviant. Expressions of Islam-inspired rap artists may reflect the needs of those in socio-economically deprived urban circumstances in the UK and the USA (see also Mandaville 2009[1]; Mohaiemen 2008[6]; Rose 1994[41]). From the concept of "the established and the outsiders" of Norbert Elias and John Scotson, the views of Muslim performing artists and ways of transforming these to art could be understood as a moral kind of counter stigmatization in order to improve the imbalanced figuration between the established and newcomers or outsiders in Muslim-minority contexts (Elias \& Scotson 1994)[43]. However, in the first place, they may be considered conventions and shared practices, which artists develop through collaboration whilst constituting an art world.

Additionally, to further understand the differences between Muslim performing artists it will be necessary to investigate which mechanisms play a role in their transnational, artistic context. I will therefore discuss seven general rules of the field of art from the concept as introduced by Pierre Bourdieu (1996, 2009)[36,37].

\subsection{The Taxonomy of the Field of Muslim Performing Artists in the UK and the USA}

According to the concept of Pierre Bourdieu, the field of art is structured by styles. Bourdieu distinguishes three styles in the nineteenth century (Bourdieu 1996)[36] (Fig. 1). Bourgeois art is near to the manners and values of the establishment. Partly, bourgeois art pursues conformist idealism and established art; partly it seeks for uncomplicated pleasures. Social art rejects the hierarchy in power relations and is concerned with social reform and ethical elevation. Useful art is a conservative substyle of social art. Art for art's sake, lastly, is focused on art itself. It is against any functional objectives of art, disinterested in moral upheaval and detached from any prevailing aesthetic taste.

To differentiate between Muslim performing artists and their considered purposeful, ethical art in the UK and the USA, I have estimated the taxonomy of the field of Muslim artists, which could be understood as co-shaping the field of art, in the reduced overview (Fig 2).

The religious style expresses moral concern that derives from literal ideas on purity in Islam and the goal of dawah to instruct other Muslims in practicing Islam. For example, Iranian American comedian Ali Ardekani aka Baba Ali seriously explains in the comical video That's not Hijab how a Muslim woman is supposed to hide her hair in an Islamically correct way. ${ }^{14}$ The moral video is part of the Reminder Series, which Baba Ali defines as "serious comedy." 15
10 For meeting respondents, I particularly used the method of online and offline snowball sampling.

11 Information about the artists derives predominantly from (a) in-depth interviews, but also from combinations of (a), (b) short interviews, (c) content analysis of secondary sources and (d) content analysis of (biographical) performances and Q\&A sessions.

12 These three artists do not self-identify as Muslim, but tend to stand for Muslims after 9/11 or are affiliated with (secularized) Sufism.

13 Using MAXQDA software for mixed qualitative and quantitative methods of analyzing, the interviews are deconstructed along sensitizing sociological concepts deriving from relational and process sociological theories, symbolic interactionist theories and self-developed categories.
14 Available: www.youtube.com/watch?v=F4jQi0Gjy3M (accessed October 13, 2014).

15 Interview with the author, Los Angeles, CA, February 11, 2010. 


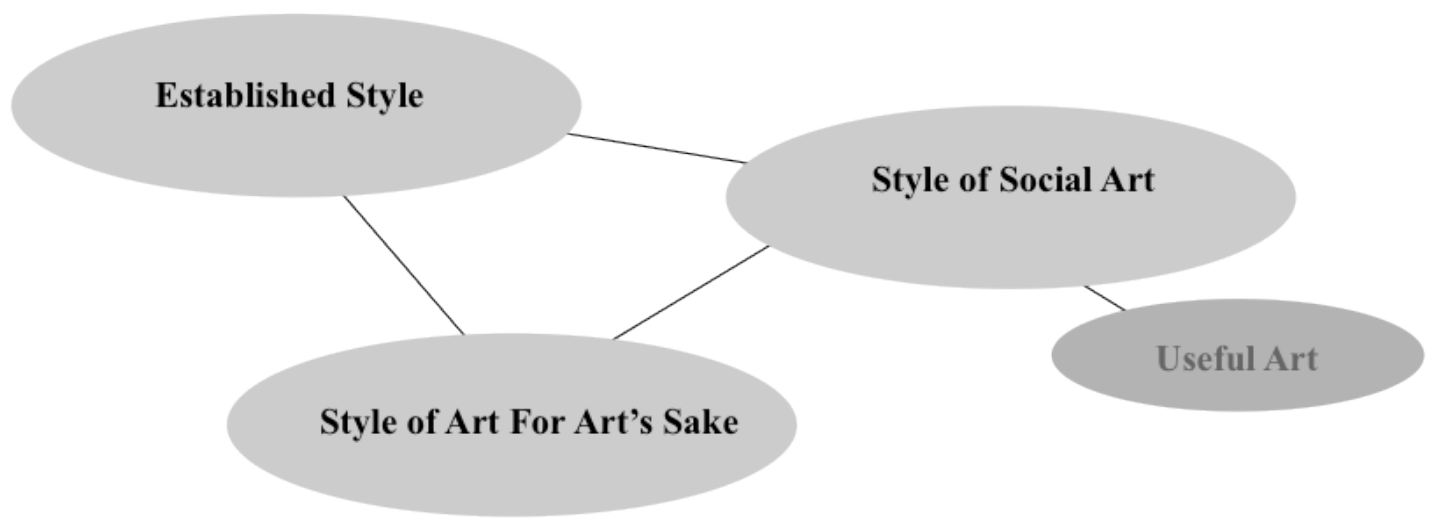

Reduced overview of the distribution of art styles at the turn of the nineteenth century (Bourdieu 1996). (C Van Tilborgh).

Figure 1. Taxonomy of the Field of Art (Bourdieu 1996)

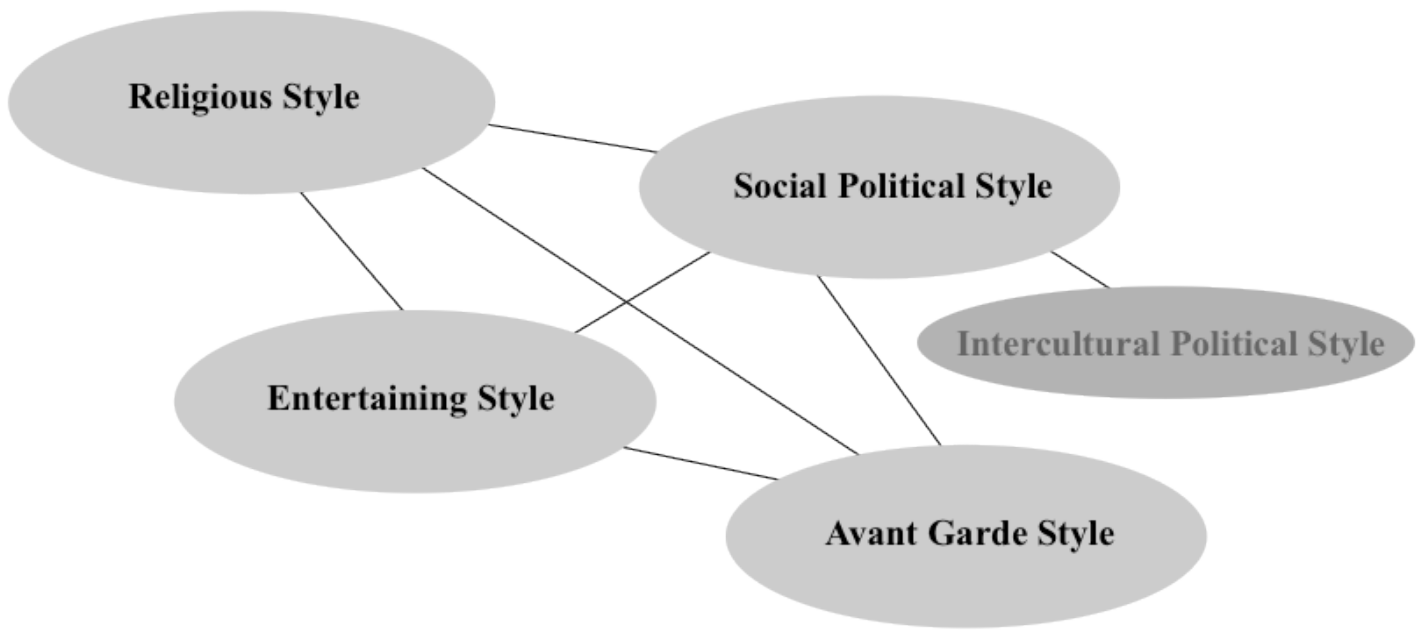

Reduced overview based on the distribution of art styles in the field of Muslim performing artists in the UK and the USA between 2009 and 2012. (C Van Tilborgh).

Figure 2. Taxonomy of the Field of Muslim Performing Artists in the UK \& the USA

The social political style displays critical notions in the form of functional entertainment, which is often called "edutainment" by the artists in hip-hop. Although these performers aim to provide a good time to their young (Muslim) audiences, their social messages of reform are often central to their musical, comical and spoken word productions. Apart from demonstrating "that not all Muslims are terrorists," British Nigerian Rakin (Fetuga) Niass, for instance, tries to convey his social worries against the glamorization of gangsta hip-hop and social ills like teenage crime. ${ }^{16}$ American Safiyyah Fatimah Abdullah, aka Phenomena, who is of mixed Native American and White descent, denounces in her poems that corporate America forces incarcerated African, Native and Hispanic Americans to work for the industry of consumption, which "chains people to materialism" like they once chained Black slaves. ${ }^{17}$

The intercultural political style tries to blend Muslim and non-Muslim perspectives. Indian American stand-up comedian Azhar Usman from the group Allah Made Me Funny, for example, firstly creates a cheerful chat with his Muslim audience about the confusion of non-Muslims regarding the various Islamic Eid celebrations that Muslims hold on to. ${ }^{18}$ Subsequently, he teaches his Muslim audience to stop complaining about misconceptions concerning Islam and better explain Eid Al Fitr and Eid Al-Adha to their non-Muslim colleagues if they ask the management for yet another day off. ${ }^{19}$

The entertaining style exercises social commentary, but its main goal is to make people laugh. It's kind of humor aligns with mainstream humor. When recounting her spiritual experience, British Pakistani comedian Shazia Mirza ${ }^{20}$ who is convinced that "Islam does not preclude joking on stage," makes fun of sexual intrusiveness during the holy pilgrimage to Mecca, the hajj. In the Muslim crowd, she suddenly felt a

18 Allah Made Me Funny, Live in Concert, at Meervaart Theater, Amsterdam, NL, September 2, 2008.

19 Interview with the author, Chicago, IL, March 17, 2010.

20 Interview with the author, London, April 1, 2009. 
hand on her bottom and thought: "It must be the hand of God." 21

Lastly, the avant-garde style in the field of Muslim artists is less occupied with specific functional outcomes than the social political style, but displays artistic and intellectual reflections in a moderately playful way. Working in contemporary art, British Yara El-Sherbini, of Egyptian and Caribbean background, assembles a bomb. While this kind of military device is used to drop a large number of bombs over a given area "like the laying of a carpet," El-Sherbini shows that some household rubbish, a cord and a (Persian) carpet are sufficient to create (the art work) $A$ Carpet Bomb. ${ }^{22}$ The artist explains that the dominant association of people and media in the West is to immediately think about Islam ("a brown Muslim woman prepares a bomb"), which neglects alternative readings. ${ }^{23}$

In the perspective of the taxonomy of the field, purposefulness is an important aspect of the religious style and social political style. However, providing a clear, unambiguous message is not primarily essential to the art of all Muslims, such as to the entertaining and avant-garde styles. Similarly, some sense of non-violent Islamist militancy is now and then obviously present at the core of the social political style, while a sense of post-Islamism seems to be inherent to the intercultural political style (see also Van Tilborgh 2016) [44].

\subsection{The Poles in the Field}

Similar to the structuring impact of styles, according to Pierre Bourdieu, poles structure the field of art (Bourdieu 1996)[36]. This means that the desire for commercial success belonging to the style of established art is in contrast with the disinterestedness in profits inherent to the style of art for art's sake. The contrasting artistic ideologies are expressed by the difference between large and small-scale productions of art and entertainment.

This may also be the case for Muslim performing artists. In non-Muslim settings, stand-up comedian Shazia Mirza, who practices an entertaining style, has a better chance to gain commercial profits in the bigger playhouses than avant-garde artist Yara El-Sherbini, who works for small art galleries.

In the field of Muslim artists, poles can frame single styles likewise. For instance, poles representing disinterestedness versus interests in commercial profits may also exist among artists of the religious style. Although they often work for charity events in community centers for small audiences, several of them meet and greet lucrative opportunities as well. African American stand-up comedian and former actor Omar Regan, ${ }^{24}$ who conveys that whereas Hollywood

21 Available at: www.sfgate.com/entertainment/article/Funny-Shazia-Mirz a-looks-Muslim-Her-2617018.php (accessed January 30, 2013).

22 Available at: lacajablanca.com/artists/artists_yarael-sherbini/viewer.swf (accessed December 23, 2012).

23 Interview with the author, London, April 20, 2009.

24 Interview with the author, Philadelphia, PA, April 24, 2010. teaches one to be a "fake" person, participating in the hajj taught him to be a "true" person, ${ }^{25}$ got the chance to perform for an international audience of several thousands of Muslims at the huge Global Peace and Unity(GPU) event in London. ${ }^{26}$ Working for "Islamic mainstream" increases the possibility of artists to achieve considerably more symbolic and economic capital.

All of these artists are Muslims. However, expressed by poles, their different religious and artistic positions structure the field of art accordingly.

\subsection{Relation with the Field of Religion}

In the perspective of Pierre Bourdieu, modern societies consist of multiple interlocked fields including the field of art, the economic field, the field of state politics and the field of religion (1996, 2009)[36,37]. These semi-autonomous fields are characterized by their own rules and hidden assumptions.

This means that the field of art and the field of religion, i.e., in the present study the field of Islam, are to a certain degree related. The degree of influence may, for instance, depend on the kind of styles and poles as described above. British Pakistani stand-up comedian Isma Almas of the entertaining style, for example, occasionally performs in entertainment clubs for gay audiences that are predominantly non-Muslim. She does not ask advice concerning her artistic content from Islamic teachers. ${ }^{27}$

In contrast, at the start of his career, when acting in a social political style, Indian American comedian Aman Ali did appreciate Islam-oriented advice. By humorously focusing on personal politics, he serves his Muslim audiences who try to synthesize their faith with daily American life. Islamic teachers who visited his shows have informed him about the sense and nonsense of his stand-up comedy to enhance "conscious comedy" instead of senseless comedy among Muslims. ${ }^{28}$ So, in front of Muslim visitors, Aman Ali rather refrains from the word "gay," because this might cause a storm of indignation among factions of audience members. Here also applies, the different religious relationships structure the positions in the field of Muslim performing artists.

\subsection{Social Categories in the Field}

Because the field is structured by art styles (Bourdieu 1996)[36], it is also structured by ethnicity and faith background. Especially in the years after 9/11, many artists of African (American) background expressed themselves regularly as Muslim in the subfield of hip-hop and popular culture. As converts to Islam and pioneers in art and music

25Available: www.youtube.com/watch? $\mathrm{v}=\mathrm{yC}$ gna-IcTI (accessed December 16, 2012).

26 Global Peace and Unity Event (GPU), London, October 23, 2010.

27 Interview with the author, Bradford, April 22, 2009.

28 Interview with the author, New York City, NY, April 5, 2010. 
related to (new) Muslims, British Nigerian Rakin (Fetuga) Niass $^{29}$ and African American Anas Canon have separately initiated poetical and musical events aimed at young Muslims to enhance their thoughts on Islam and being Muslims in the UK and the USA respectively. ${ }^{30}$

In the subfield of stand-up comedy, South Asian and Middle Eastern artists from the entertaining style who are born-into Islam explore particularly their ethnic background and experiences instead of their religiousness. They express that being (second generation) immigrant and being Muslim are (different) aspects of their identity. Whereas British Pakistani stand-up comedian Sajeela Kershi of the hilarious duo Asian Provocateurs: Rule Britannia! discussed herself and her experiences as daughter of an immigrant in Britain in 2011, ${ }^{31}$ Egyptian American Ahmed Ahmed had become engaged in the Axis of Evil Comedy Tour in 2005, featuring Middle Eastern comedians who combat their post 9/11 stigmatization in the USA. ${ }^{32}$

In these perspectives, ethnic identity may compete with religious identity in gaining and maintaining positions in the field of art.

\subsection{Dynamics in the Field}

The field of art is not a static entity, because dynamics structure the field (Bourdieu 1996) [36]. Dynamics may be caused by external changes. Before the terrorist attacks in 2001, particularly White, indigenous, non-Muslim male artists dominated the genre of comedy. After $9 / 11$, especially (female, Muslim) performing artists from immigrant descent dared to enter the subfield of stand-up comedy to let their voices be heard. Their entertaining and confrontational performances formed a complaint against stigmatization of all Muslims. However some female performances, for example of Iranian American Tissa Hami, could also be understood as a complaint against the reintroduced moral conventions of the religious style in the field of Muslim artists and of restrictive Muslims in general. ${ }^{33}$ In one of her acts, dressed in black hijab, Tissa Hami explains that, whenever she feels "slutty," she decides to wear a short black coat, instead of a long one. ${ }^{34}$

Dynamics can also be caused by personal changes related to the discourse on art and Islam and the influence of the Islamic Revival (see also Van Tilborgh 2009)[45]. In the subfield of hip-hop, British Mozambican rap artist Mohammed Yahya is inspired by the West African habitus and music. ${ }^{35}$ West African culture is influenced by the mystical Islamic tradition of Sufism to which the relation between beauty, art and God is a key element (Winegar

29 Interview with the author, London, October 20, 2010

30 Interview with the author, Los Angeles, CA, January 15, 2010.

31 Interview with the author, London, September 1, 2009.

32 Short interview with the author, New York City, NY, April 20, 2010.

33 Interview with the author, San Francisco, CA, February 17, 2010.

34 Available at: www.brownalumnimagazine.com/content/view/882/40/ (accessed November 30, 2015).

35 Interview with the author, London, March 24, 2009.
2008)[11]. In the course of his career, Yahya has drawn toward the style of more musicality and singing female voices. In contrast, rap artist Spitz Yaqub Abdusalaam has become inspired by Salafi lectures. The conservative scripturist Islamic orientation of Salafism tends to restrict art and music. Spitz has turned his attention increasingly to the style of spoken word, without using musical instruments any longer, let alone female voices. ${ }^{36}$

Diverse sources of inspiration thus influence the dynamics of artistic positions in the field. They derive from collective experiences of social injustice and shared ethnic roots or in the course of developing personal views regarding the "right" kind of social behavior in relation to the Islamic Revival and the dominant discourse on art in Islam.

\subsection{History of the Field}

The history of the field of art is yet another factor in structuring the field (Bourdieu 1996)[36]. In case of the field of Muslim performing artists, after 9/11, African American Muslim converts did not really have to discover the power of art to fight social injustice as many artists of immigrant descent had to. African Americans have a common history in art based on the Civil Rights Movement, the Black Power Movement and its sister the Black Arts Movement (BAM). Moreover, African Americans and a number of Muslims among them have an important share in the development of the musical traditions of blues, jazz and hip-hop. In its significance to the field of Muslim performing artists, this history is not specifically Muslim but rooted in race experiences and different views to culture (see also Van Tilborgh 2016)[44].

\subsection{The Power to Define}

The hierarchy in the field is structured by cultural definitions of those who have the power to influence the degree of dominance of certain definitions (Bourdieu 1996)[36]. In the case of the field of Muslim performing artists, these may concern a combination of artistic and religious values. African American music producer Anas Canon collaborated with British Jamaican rap artists Poetic Pilgrimage $^{37}$ to make the album Congo Square. He has bid the Muslim women Muneera Rashida and Sukina Abdul Noor to rap about "love" instead of "Palestine," or about (Black) Muslims dying in Africa instead of Muslims only dying in Palestine. ${ }^{38}$ This may be about the competition between Islamist and post-Islamist themes; it may also concern the broader competition between themes of indigenous (Black) artists and immigrant artists, who are supposed to have different interests with regard to the social hierarchy in Islam and the image of the USA (see also Khan 2003[18]; Aidi 2014[13]).

36 Interview with the author, London, December 16, 2010.

37 Interview with the author, London, December 6, 2010.

38 Interview with the author, Los Angeles, CA, January 15, 2010. 
Most Muslim performing artists do not identify with the definitions "Muslim rap," or "Islamic art." Artists of the religious style, for instance, state that there is no Muslim rap that could meet real Islamic standards, whereas avant-garde artists perceive that the term Islamic art reduces them as professional, autonomous artists.

External and internal problems of the Muslim community can also be in competition to become on top of the list of themes in the field of Muslim performing artists. In his tradition to provoke thought and debate and particularly "move the narratives out of the old colonial opinions" in order to make immigrants feel part of society, British Pakistani Aki Nawaz, leader of the political punk-rock group Fun-Da-Mental, made the album All is War: the Benefits of G-Had in 2006. ${ }^{39}$ He rejects what he calls "slaughter of Muslims wholesale" and how "the West has been manipulating politics for its own ends across the globe" (see also Swedenburg 2001)[8]. ${ }^{40}$ Several years later, on the other pole, Poetic Pilgrimage attacked Middle Eastern Muslim leaders before the start of the "Arab Spring" in the music video Silence is consent. They rap: "You keep quiet while people are dying". ${ }^{1}$

Obviously, in defining what is urgent, the field of Muslim performing artists has more goals than tackling stigmatization by non-Muslim majority societies and their questionable policies abroad. Already before the onslaught of the Islamic State (IS, ISIS or Daesh), Muslim artists pointed at different internal targets in the overall Muslim community as well.

\subsection{Conversion Strategies}

Participants of the field of art develop strategies to transform certain forms of capital (Bourdieu 1996)[36]. All artists are eager to control possible material and symbolic profits in the field. For example, when British Pakistani Jeff Mirza started as a comedian, his brothers in faith told him it is haram to make people laugh while people in Palestine are crying. ${ }^{42}$ Mirza made his jokes, an expression of cultural capital, more legitimate to the Muslim community by often performing at charity events for Muslim and South Asian organizations, to benefit the victims in Gaza. In the form of respect, this brought him symbolic capital as well: He received the Muslim Award of the British House of Lords for his contribution to the Muslim community.

British Nigerian rap artist Rakin Niass makes a cappella versions of his rap songs, i.e., he makes his songs both with and without musical instruments. ${ }^{43}$ This way, both mainstream art managers and orthodox Muslim agents are

39 Available at: www.theguardian.com/music/2006/jul/16/11 (accessed November 30,2015). And: correspondence with the author, March 22, 2016 40 Fareena Alam. "Another Inconvenient Truth." Q-News 2006 (September/October): 368. And: correspondence with the author, March 22, 2016.

41 Available at: www.youtube.com/watch?v=z1 orCqZg4SA

(accessed November 30, 2015).

42 Interview with the author, London, April 18, 2009

43 Interview with the author, London, October 20, 2010. able to give him commissions. Without having to adapt his artistic and religious views or transforming his orientation from Sufism to Salafism, this kind of conversion strategy may grant Niass more material and symbolic capital.

\subsection{Strategies of Distinction}

To enrich their symbolic capital and safeguard their social status, artists develop strategies of cultural distinction (Bourdieu 1996, 2004)[36,46]. For example, because new artists are eager to gain the privileges of established artists, and established artists are ambitious to maintain their position. British Pakistani Naz Koser started in the field of art with a creative enterprise for the empowerment of Muslim and immigrant women. ${ }^{44}$ She presented the logo of enterprise Ulfah Arts in Arabic style, which was perceived as ultimately Islamic by Muslims and non-Muslims. After a few years, when many socio-cultural companies that focused on Muslims entered the field of Muslim artists with their obviously Islamic designs, she changed the Ulfah Arts logo by exclusively using mainstream roman lettering. Naz Koser had already proven her Islam-oriented intentions. With the logo transformed from an oriental to a Western appearance, she started to present herself as the more established creative director and artist who has achieved a degree of social mobility in the field of art and would like to distinguish herself and the company from other Islamically oriented new artists and organizations in the same field.

\section{Conclusions}

In the field of British and North American Muslim performing artists, Islamic Revival, post-Islamism, Muslim culture and Islamic purposefulness can be understood as important aspects, but the practices of Muslim artists cannot be reduced to these terms. It is not just that the field produces Islamist as well as post-Islamist kind of expressions. The point being, not all artists are equally inspired by the trend toward greater piety. Unfortunately, among social scientists there is a certain tendency to focus on Muslim artists and Muslims who display obvious religiosity in their expressions.

The perspectives of symbolic interactionist, process and relational sociology are helpful to discuss and explain several significant understandings of Muslims, their practices and discourse regarding (popular) art. Applying "the rules of art" from the relational sociological theory of Pierre Bourdieu on "the field of cultural production" to the practices and sayings of Muslim performing artists, I found that the field of Muslim performing artists is not a homogeneous whole but a rather structured, differentiated field instead. This observation shows diversity and distinctiveness among Muslim artists expressed by a huge

44 Interview with the author, Birmingham, March 23, 2009 \& December 13, 2010 
differentiation in artistic styles and approaches, resulting in a range of religious to more secularized productions of art.

Comparable to the field of art, the (sub)field of Muslim performing artists is structured by means of artistic styles, poles of large and small-scale productions and poles of commercial interestedness and disinterestedness. Commercial disinterestedness may coincide with religious views, for instance concerning modest behavior. Muslim performances are not just religious or proselytizing expressions and critical utterances toward non-Muslim Western tastes and powers, but also (self) critical utterances toward Muslim powers. Choices might be spiritually motivated but also influenced by the struggle to maintain or improve one's position. In other words, in the field of Muslim artists, strategies of cultural distinction and conversion strategies to rise socially are as common as in the general field of art.

The rules in the field of art reveal that the preferences of Muslim artists with regard to artistic themes and approaches are significantly determined by different notions on the relation between culture, ethnicity and Islam. The awareness of ethnic or racial identity may lead to different choices in defining spiritual values, which influence how the styles of art, approaches and views socially construct the positions in the field of Muslim performing artists.

Studying the kind of artistic expressions, the dynamics in the field of Muslim performing artists reflect opposite directions in terms of secularization and the trend toward greater piety. These directions vary according to the different relationships assigned to faith and culture or ethnicity.

Rather contrary to the field of art, the (sub)field of Muslim performing artists has a variable kind of relationship with the field of religion, i.e., in the present study the (sub)field of Islam. However, these relationships vary from a significantly positive to a rather non-existing or near to negative kind of relation, which influence the poles in the field, such as through different styles or artistic poles.

In sum, although artistic practices of Muslims tend to be understood as religious and specific to Muslims, through the perspectives of the rules of the field of art they can as much be understood as influenced by secular mechanisms, which are significant to all artists, Muslim and non-Muslim. Aiming to make better sense of Muslim performing artists and their practices by not just observing the development of a Muslim culture, it is insightful to focus on the mechanisms of the field of cultural production through investigating the field's history, dynamics, taxonomy, poles, defining power, strategies of distinction, conversion strategies, etcetera. This investigation demonstrates that many of the artists' practices are notably constituted by the structuring of the field through the mechanisms of competition and socio-cultural improvement. In other words, the considered religious artistic features of quite a few practices in the field of Muslim artists coincide significantly with various secular mechanisms in the field of art in general. Altogether, the theories of process and relational sociology may provide alternative insights that prevent regarding Muslims as culturally considerably different from other cultured human beings.

\section{Acknowledgements}

This paper is developed from the author's lectures British and American Muslim Artists Regarding Bourdieu's Field of Art at the ESA Conference in Turin, Italy, 2013, and The Rules of Art and the Field of Muslim Performing Artists in the UK \& the USA at the ESA Conference in Cluj Napoca, Romania, 2014. The author would like to thank Prof. Nico Wilterdink, MA Irene Timmer MSc and Claire Meeussen MSc for their important suggestions to improve this lecture, and Dr. Bart van Heerikhuizen for his general remarks on the topic concerned.

\section{REFERENCES}

[1] Mandaville, Peter. "Hip-hop, Nasheeds, and 'Cool' Sheikhs: Popular Culture and Muslim Youth in the United Kingdom." In-Between Spaces: Christian and Muslim Minorities in Transition in Europe and the Middle East. Eds. Christiane Timmerman, Johan Leman, Hannelore Roos and Barbara Segaert. Leuven: Peter Lang, 2009: 149-68.

[2] Abdul-Khabeer, Suad. "Rep that Islam1: The Rhyme and Reason of American Hip-Hop." The Muslim World 97(1) 2007: 125-41.

[3] Boubekeur, Amel. "Post Islamist Culture: A New Form of Mobilization?" History of Religions 74(1) 2007: 75-94.

[4] Herding, Maruta. Inventing the Muslim Cool. Islamic Youth Culture in Western Europe. Bielefeld: Transcript Verlag, 2013.

[5] Kubala, Patricia. "The Other Face of the Video Clip: Sami Yusuf and the Call for al-Fann al-Hadif." Transnational Broadcasting Studies 14(2) 2005: 38-47. Available at: tbsjournal.arabmediasociety.com/Archives/Spring05/kubala. html

[6] Mohaiemen, Naeem. "Fear of a Muslim Planet: The Islamic Roots of Hip-Hop." Ed. DJ Spooky. Sound Unbound: Sampling Digital Music and Culture. Cambridge, MA: MIT Press, 2008: 303-325.

[7] Solomon, Thomas. Hardcore Muslims: Islamic Themes in Turkish Rap in Diaspora and in the Homeland. Yearbook for Traditional Music 38, 2006: 59-78.

[8] Swedenburg, Ted. "Islamic Hip-Hop versus Islamophobia: Aki Nawaz, Natacha Atlas, Akhenaton.” Ed. Tony Mitchell. Global Noise: Rap and Hip-Hop outside the USA. Middletown, CT: Westleyan University Press, 2001.

[9] Tartoussieh, Karim. "Pious Stardom: Cinema and the Islamic Revival in Egypt." The Arab Studies Journal 17(1) 2007: 3044.

[10] Van Nieuwkerk, Karin. "New Religiosity and 'Fann al-Hadif', 'Art with a Mission,' in Egypt." Paper for ESF Exploratory Workshop Islamization of the Cultural Sphere? Critical 
Perspectives on Islam and the Performing Arts in Western Europe and the Middle East. Amsterdam, October 22-25, 2008.

[11] Winegar, Jessica. "Purposeful Art: Between Television Preachers and the State." ISIM Review 22 (autumn) 2008: 2829.

[12] Brown, Frank B. Good Taste, Bad Taste, and Christian Taste: Aesthetics in Religious Life. New York: Oxford University Press, 2000.

[13] Aidi, Hisham D. Rebel Music: Race, Empire, and the New Muslim Youth Culture. New York: Pantheon Books, 2014.

[14] Bayat, Asef. Islamism and the Politics of Fun. Public Culture 19(3) 2007: 433-459.

[15] Otterbeck, Jonas. "Battling over the Public Sphere: Islamic Reactions to the Music of Today." Contemporary Islam 2(3) 2008: 211-228.

[16] Shiloah, Amnon. Music in the World of Islam: A Socio-Cultural Study. London: Scolar Press, 1995.

[17] Lapidus, Ira M. A History of Islamic Societies, Cambridge, UK: Cambridge University Press, 2002.

[18] Khan, Muqtedar. "Constructing the American Muslim Community." Religion and Immigration: Christian, Jewish, and Muslim Experiences in the United States. Walnut Creek, CA: AltaMira Press, 2003.

[19] Esposito, John L. Islam and Politics. New York: Syracuse University Press, 1998 [1984].

[20] Kepel, Gilles. Jihad: The Trail of Political Islam. Trans. Anthony F. Roberts. New York: I.B. Tauris, 2006 [2002].

[21] Roy, Olivier. Globalized Islam: The Search for a New Ummah. London: Colombia University Press, 2004.

[22] Baker, Raymond W. Islam Without Fear: Egypt and the New Islamists. Cambridge MA: Harvard University Press, 2003.

[23] Al-Qaradawi, Yusuf. Fi fiqh al-aqalliyyat al-muslima. hayat al-muslimin wasat al-mujtama'at al-ukhra. Cairo: Dar al-Shuruq, 2001.

[24] Gräf, Bettina. "Yusuf al-Qaradawi." The Oxford Handbook of Islam and Politics. Eds. John L. Esposito and Emad el-Din Shahin. Oxford: Oxford University Press, 2013: 222-236.

[25] Bayat, Asef. Making Islam Democratic: Social Movements and the Post-Islamist Turn. Stanford, CA: Stanford University Press, 2007.

[26] Bayat, Asef, ed. Post Islamism: The Changing Faces of Political Islam. New York, NY: University Press, 2013.

[27] LeVine, Mark. "Heavy Metal Muslims: the Rise of a Post-Islamist Public Sphere." Contemporary Islam 01(2) 2008: 229-249.

[28] Mamdani, Mahmood. Good Muslim, Bad Muslim: America, the Cold War, and the Roots of Terror. New York NY: Random House LLC, 2005.

[29] Morey, Peter and Amina Yaqin. Framing Muslims. Stereotyping and Representation after 9/11. Cambridge, MA: Harvard University Press, 2011.

[30] Alim, H. Samy. "A New Research Agenda: Exploring the
Transglobal Hip Hop Umma." Muslim Networks: From Haij to Hip Hop. Eds. Miriam Cook and Bruce B. Lawrence. Chapel Hill, NC: The University of North Carolina Press, 2005: 264-74.

[31] Sunier, Thijl. "Beyond the Domestication of Islam in Europe: A Reflection on Past and Future Research on Islam in European Societies." Journal of Muslims in Europe 1(2) 2012: 189-208.

[32] Brubaker, R. and F. Cooper. "Beyond 'identity". Theory and Society 29(1) 2000: 1-47.

[33] Casanova, José. Public Religions in the Modern World. Chicago: The University of Chicago Press, 1994.

[34] Casanova, José. "Religion, European secular identities, and European integration." Eds. Tymothy A. Byrnes and Peter A. Katzenstein. Religion in an Expanding Europe. Cambridge: Cambridge University Press, 2004: 65-92.

[35] Becker, Howard S. Art Worlds. Ewing, NJ: University of California Press, 1982.

[36] Bourdieu, Pierre. The Rules of Art: Genesis and Structure of the Literary Field. Trans. Susan Emanuel. Stanford, CA: Stanford University Press, 1996 [1992].

[37] Bourdieu, Pierre. The Field of Cultural Production: Essays on Art and Literature. Ed. and intro. Randal Johnson. Cambridge, UK: Polity Press, 2009 [1993].

[38] Van Nieuwkerk, Karin (ed.). Muslim Rap, Halal Soaps and Revolutionary Theater: Artistic Developments in the Muslim World. Austin: University of Texas Press, 2011.

[39] Horkheimer, Max \& Adorno, Theodor W. Dialectic of Enlightenment: Philosophical Fragments. Chicago: Stanford University Press, 2002 [1947].

[40] Shaheen, Jack G. Reel Bad Arabs: How Hollywood Vilifies a People. New York: Olive Branch Press, 2001.

[41] Rose, Tricia. Black Noise: Rap Music and Black Culture in Contemporary America. London: University Press of New England, 1994.

[42] Rose, Tricia. The Hip Hop Wars: What We Talk About When We Talk About Hip Hop-and Why It Matters. New York: Basic Books, 2008.

[43] Elias, Norbert and John L. Scotson. The Established and the Outsiders: A Sociological Enquiry into Community Problems. London: Sage Publications, 1994 [1965].

[44] Van Tilborgh, Yolanda. "From Hell to Heaven: The Malcolm $X$ Narrative of Muslim Artists. The Meaning of his Life in Relation to the Doctrine of Predestination for British and American Performing Artists in the $21^{\text {th }}$ Century." In Malcolm X: From Political Eschatology to Religious Revolutionary, eds. Dustin J. Byrd and Seyed Javad Miri. Leiden: Brill, 2016: 273-320.

[45] Van Tilborgh, Yolanda. Het islamdebat en de strategische emoties van moslima's. Jaarboek KennisSamenleving: Gevoel voor kennis. Amsterdam: Uitgeverij Aksant, 2009: 98-120.

[46] Bourdieu, Pierre. Distinction: A Social Critique of the Judgement of Taste. Richard Nice (trans.) London: Routledge \& Kegan Paul Ltd., 2004 [1979]. 